\title{
Campanhas publicitárias na revista Veja: construções da globalização*
}

\author{
Alessandra Lemos de Oliveira ${ }^{I}$ \\ Angela Maria Rubel Fanini ${ }^{2}$ \\ Maurini Souza $a^{3}$ \\ Universidade Tecnológica Federal do Paraná
}

Neste artigo, analisam-se quatro peças publicitárias extraídas da revista Veja em diferentes décadas, procurando perceber como o discurso publicitário engendra visões da globalização. Aborda-se a publicidade enquanto uma ferramenta a serviço da lógica do capitalismo e do consumismo. Verificou-se que a passagem temporal, embora implique modificações formais e de conteúdo nas peças analisadas, revela-se também uma constante em que, a partir da publicidade, promete-se a inserção dos públicos alvos na globalização tomada somente em seus aspectos positivos, fortalecendo a idéia de globalização perversa e à maneira de fábula, tipologia proposta pelo pensador Milton Santos que se debruçou sobre as relações entre publicidade e mundialização.

Palavras-chave: Globalização perversa Globalização como Fábula - Discurso Publicitário - Consumismo - Revista Veja .
This paper analyses four media advertisements in Veja magazine during different decades, searching for globalization visions constructed in that source. Media advertisements are viewed as tools for reinforcing capitalism and consumption. It is verified that, although there are differences related to content and formal aspects in the ads, due to the passage of time, there is a constant positive perspective towards consumption through which the target public can reach a better life in an international community. This view reinsures what the Brazilian thinker Milton Santos says about globalization, which appears as perverse and as fiction in propagandas and ads.

Keywords: Perverse globalization - Fictional globalization - Advertisements - Consumption - Veja magazine.

\section{Introdução: globalização, publicidade e consumo}

A cada tempo, a sociedade passa por mudanças que a levam a incorporar - novas palavras para expressar, problematizar e analisar essa mesma sociedade ${ }^{4}$.

* Media advertisements in Veja magazine: perspectives on globalization

${ }^{1}$ Mestre do Programa de Pós-Graduação em Tecnologia, UTFPR, Curitiba, PR (alelemos50@yahoo.com.br).

${ }^{2}$ Prof $^{a}$. Dr ${ }^{\mathrm{a}}$ do curso de Comunicação, Letras e do PPG em Tecnologia da UTFPR (rubel@utfpr.edu.br).

${ }^{3}$ Prof $^{a}$. Dra . do curso de Comunicação e Letras da UTFPR, Curitiba, PR. Endereço para correspondências: Av. Sete de Setembro, 3165, Rebouças, Curitiba, PR, 80230-901 (maurinis@yahoo.com.br).

${ }^{4}$ Hobsbawn (1995) menciona essas novas palavras que expressam novos momentos sociais ao tratar da Revolução Francesa e Industrial. Logo na introdução da obra, o autor afirma que "as palavras são testemunhas que muitas vezes falam mais alto que os documentos". O historiador vê a relação das palavras e das coisas, não advogando uma visão idealista da linguagem. (HOBSBAWN, 1995, p. 2). 


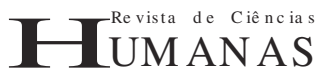

Se antes da Revolução Industrial não havia sentido em se falar em fábrica, classe trabalhadora ou greve, no século 20 e no atual século 21, novos vocábulos também representam transformações pelas quais o mundo passa. Entre os termos, está a publicidade, a comunicação digital e eletrônica, a internet e a globalização. Esta última tem sido alvo de intensos debates, sobretudo a partir da década de noventa do século 20. Muitos a vêem por intermédio de uma visão positiva; outros negativa e ainda há aqueles que apresentam aspectos positivos e negativos. Sendo assim, há uma multiplicidade discursiva em torno da globalização, tornando o assunto polêmico e de difícil definição absoluta. Neste artigo, percebe-se a globalização a partir de uma abordagem históricocrítica em que se focaliza a questão do fortalecimento do Capitalismo ${ }^{5}$ e do mercado como características acentuadas da globalização. Nesse contexto de intensificação do capital, vê-se também a linguagem da publicidade como uma forte ferramenta que contribui para tal fortalecimento.

Neste estudo, anúncios publicitários na revista Veja das décadas de setenta, oitenta e noventa se tornam objeto de análise para se verificar a presença da globalização enquanto um cenário de reforço de uma visão mercantilizada vinculada ao sistema de produção capitalista. A partir de bases teóricas advindas da Análise do Discurso francesa, interpretam-se as peças publicitárias do referido corpus, buscando identificar o sujeito emissor, suas intenções e estratégias discursivas e a construção do receptor no interior do discurso. A análise se justifica por alguns aspectos. Entre eles, o fato de a revista Veja ser considerada um veículo de comunicação com forte papel de formação ideológica no Brasil. Morais (1994), citando Assis Chateaubriand ${ }^{6}$, atribui a este a seguinte constatação: a de que a classe média brasileira, quando quer construir uma opinião mais sólida sobre os fatos, lê revista, acreditando que aí os fatos e situações estejam melhor e mais fidedignamente documentados e explicados. Essa constatação é já sedimentada na área do jornalismo. As campanhas publicitárias postadas em revistas acabam por ser impactadas por essa credibilidade do veículo. Essa perspectiva permite pressupor que analisar o que a revista Veja apresenta em seus anúncios publicitários é um ponto de partida para se ter uma ideia do que o público pode ser levado a considerar a respeito da globalização,

${ }^{5}$ Jameson (2008) destaca a permanência do sistema capitalista na atualidade, sobretudo a versão neoliberal americana, e suas articulações com um determinado universo simbólico que visa reforçar aquele modo de produção. Enfatiza a força do âmbito econômico, seguindo Marx, e suas interações com o universo cultural e político. Capitalismo e globalização são partes de um mesmo sistema. A indústria cultural se ancora na publicidade, veículo e ferramenta que fomenta o consumo e fortalece o Capital. Destaca-se o papel da publicidade como veículo da gobalização econômica. A linguagem publicitária oblitera o processo do trabalho na esfera da produção, focando-se na "livre" circulação e consumo de artefatos e bens.

${ }^{6} \mathrm{O}$ empresário Assis Chateaubriand foi proprietário de um dos principais grupos de comunicação do Brasil, os Diários Associados. Em 1928, cria o periódico O Cruzeiro, considerado um marco do jornalismo em revistas no país. Nessa mesma fase, integra-se também ao grupo outra publicação, $A$ Cigarra, criada em 191, e que passou a fazer parte dos Diários Associados. (Nascimento, 2002, p. 17). 


\section{Campanhas publicitárias na revista Veja: construções da globalização} A.L. de Oliveira, A.M.R. Fanini \& M. Souza

do consumo e de si mesmo. A análise não se foca no público leitor real, mas nas imagens discursivas que são construídas desse público no interior do discurso publicitário. Entretanto, essa imagem discursiva pode afetar o público leitor uma vez que ele é informado, instruído e seduzido pelo discurso publicitário, visto que atua como consumidor dos produtos, marcas e serviços ali apresentados. A ligação entre o discurso publicitário e o consumo ocorre ${ }^{7}$, mas obviamente que não de igual modo para todo o receptor. Todavia, o exercício do consumo existe na realidade e pode ter ligação com a publicidade. Estudar essas campanhas pode contribuir para desenhar um certo discurso legitimado pelo veículo jornalístico de prestígio social sobre a globalização, seu viés capitalista e o consumo, seu correlato.

Mesmo com o crescimento de outras mídias, como a televisão e a internet, as revistas ainda têm uma grande força no Brasil como veículos de comunicação de massa, principalmente na formação de opinião do seu público. Segundo Viana (2006), as pessoas recebem informações ao ter acesso a pequenas notícias na web ou em jornais impressos, mas, quando desejam se aprofundar e tomar posições sobre uma determinada questão, optam pela compra de revistas semanais de informação. A teoria é válida fundamentalmente para as classes mais abastadas, que são o principal público-alvo desses veículos de comunicação. Dentro desse contexto, a revista Veja exerce particular influência. É a publicação mais lida no Brasil; por exemplo, a edição de 06.01.2010 teve uma tiragem de 1.232.888 exemplares ${ }^{8}$.

Criada em 1968, a revista Veja passou por diferentes períodos da história da Brasil e, ainda hoje, segundo Nascimento (2002), lidera o mercado de revistas no país. Com tal penetração, Veja traz leituras sobre as transformações passadas pelo país e pelo mundo ao longo desses anos,

\footnotetext{
${ }^{7}$ Baudrillhard (2000) enfatiza a relevância cada vez maior do mundo dos objetos na sociedade de consumo. O avanço das tecnologias traz uma sociedade da abundância e do bem-estar material. A linguagem publicitária encontra nessa sociedade sua razão de ser, ampliando as necessidades e desejos, embasando a lógica capitalista da incessante produção de bens e serviços sempre novos e disponíveis. Em vez de atitudes radicais e revolucionárias, impera a busca incessante de bem-estar no âmbito dos objetos. O autor aponta para a problemática situação atual em que o consumo transformou-se na moral social, na qualidade de um novo mito inquestionável. Bauman (1997) também enfatiza, na modernidade, a queda do cidadão e a ascensão do consumidor, implicando inclusive o enfraquecimento do espírito coletivo e na ênfase no indivíduo. Os agentes publicitários, para o autor, estão no topo da pirâmide do sistema capitalista visto serem os fomentadores intelectuais do consumo, sustentação do sistema. Para o autor, a sociedade individualizada deve ser repensada a partir da reinstalação da Ágora grega a fim de se impedir o processo de destruição social atualmente em curso.

${ }^{8} \mathrm{O}$ periódico foi criado em 1968 pelos jornalistas Victor Civita e Mino Carta e trata de temas de âmbito nacional e global, sendo de distribuição semanal, publicado pela Editora Abril. Com uma tiragem superior a um milhão de cópias, sendo a maioria de assinaturas, a revista Veja é a de maior circulação nacional. Para a história do surgimento da revista Veja, como modelo exemplar da transição do jornalismo artesanal para o industrial, e de como se consolidou no mercado de bens simbólicos no Brasil, ocorrido no fim dos anos sessenta a partir do projeto de modernização do país, pesquisar em Villalta (1999). Essa autora salienta que o periódico se utiliza de linguagem interpretativa para a análise dos fatos noticiados, orientando-se pelos consagrados modelos norte-americanos das revistas Time (primeira edição de 1923) e Newsweek (fundada 1933), primando, no entanto, por um estilo próprio e singularmente demarcado.
} 


\section{HUM AN AS}

desde a época da ditadura militar em que foi criada. É possível observar esse caminhar pela história e as mudanças tecnológicas que a acompanharam não apenas em suas reportagens, mas também na publicidade: "Nenhum dos jornais brasileiros figura entre os cem maiores do mundo, mas a revista Veja, inspirada no modelo da revista Time $e^{9}$, é considerada a quinta publicação do gênero em circulação no planeta, com mais de um milhão de exemplares semanais." (VIANA, 2006; p. 34). Esse periódico também tem sido alvo de inúmeras pesquisas acadêmicas sobre temáticas diversas, pois consultando-se o sítio da Capes, ali encontra-se vasto material bibliográfico proveniente de dissertações e teses. Nesse passo, esta pesquisa se justifica à medida que especificamente sobre representações discursivas em torno da globalização não se encontrou investigação.

Para a pesquisa, foram selecionados quatro anúncios: a do rádio Philips, de maio de 1970, a do aparelho de som CCE e do tênis TRX-Competition, ambos de maio de 1980, e ainda do relógio da rede H.Stern, veiculado em maio de 2000. Com a escolha dos anúncios de diferentes décadas, pretendeu-se verificar as mudanças e as permanências de certas estratégias discursivas na apresentação dos objetos de consumo, tendo na publicidade um reforço da ideia de mundialização de padrões de consumo e da prática capitalista.

\section{Globalização sob a perspectiva de Milton Santos}

Para verificar as representações da globalização expressas nos anúncios publicitários da revista Veja, este estudo usa como principal fonte de referência Santos (2000), autor de Por uma outra globalização: do pensamento único à consciência universal.

É possível perceber na obra o contexto histórico em que foi escrita: a virada do século 20 para 21, um período que Santos denomina de uma "época de transição em marcha". Santos apresenta esse termo, na sexta parte da obra em tela, revelando sua visão política positiva que consiste em apresentar certas saídas para os impasses e malefícios da globalização "perversa". O autor brasileiro aposta que a diversidade e a especificidade cultural e econômica dos países do hemisfério sul pode alterar o curso de uniformização da cultura globalizada. Destaca que na periferia do sistema capitalista podem surgir manifestações de resistência à globalização advinda dos países centrais, vinculando-as a um período já em curso a que denomina de "época de transição em marcha". O autor considera a existência de algumas mudanças sociais que o levam a propor uma globalização com novas bases, como o título menciona.

${ }^{9}$ Time Magazine é uma das publicações periódicas mais conceituadas dos Estados Unidos, criada em 1923, introduzindo o conceito de revista semanal de notícias. 
Há aí uma nova visão da História em que nessa transição poderiam imperar outras diretrizes, tais como um outro humanismo cuja centralidade seria o homem e a solidariedade e não mais o "império do dinheiro e da economização da vida". Essa transição é impulsionada, sobretudo, pela consciência que os menos favorecidos vão adquirindo, paulatinamente, ao se verem alijados da sociedade da abundância pregada e veiculada pela publicidade de bens e serviços. A uniformização de padrões de consumo vinculada pela globalização do capital também é refutada uma vez que não atende às especificidades culturais das culturas locais.

O estudioso conceitua três tipos de globalização. A primeira seria como uma "fábula", aquela que é explicada e contada principalmente por meio da comunicação de massa. Segundo o autor, são as representações da globalização na mídia, na publicidade e na chamada indústria cultural $^{10}$, procurando sempre enfatizar os supostos lados "positivos" da mundialização, sem mencionar seus possíveis danos. Uma das fábulas se reporta à idéia de McLuhan (1964) de que fazemos parte de uma aldeia global, com o fim das distâncias temporais e espaciais como fatores preponderantes na questão da reunião e comunhão de pessoas. Já não seria necessário em todos os casos estradas ou aviões para transportar cidadãos de um lado para outro visto que a tecnologia da informação, vinculada à telecomunicação, assegura essa possibilidade:

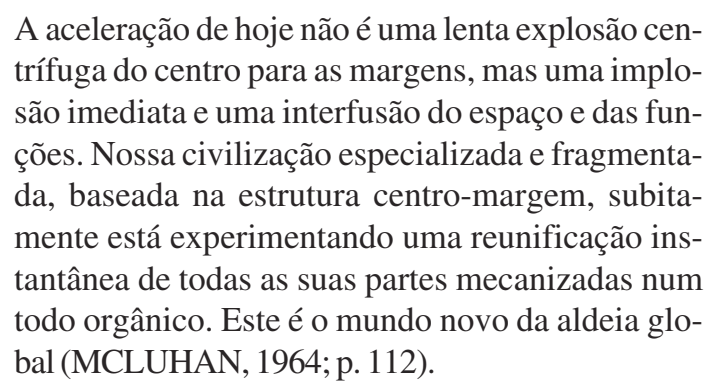

Segundo Santos, a "fábula" da globalização oferece os meios de comunicação como capazes de realizar esse transporte, que pode levar "todos" para qualquer lugar, apenas com um clique no mouse do computador ou no botão do controle remoto do aparelho de televisão. O autor brasileiro salienta que o vocábulo "todos" deve ser questionado, uma vez que não considera as diferenças econômicas e de classe social. Aceitar a ideia de que todas as pessoas seriam beneficiárias desse processo e teriam acesso a essas tecnologias é um dos grandes mitos da globalização, pois não corresponde à realidade.

\footnotetext{
${ }^{10} \mathrm{O}$ termo indústria cultural citado se refere às teorias da Escola de Frankfurt que analisam o uso de tecnologias, como rádio, televisão e cinema, pelas classes dominantes, para transformar a cultura em mercadoria, disseminando ideias capitalistas, sem estímulo ao pensamento reflexivo. A lógica do capital, da intensificação do consumo e do lucro, também se apodera dos meios de comunicação citados, mercantilizando a cultura, transformando-a em cultura de massa e para o mercado (FREITAG, 1990).
} 


\section{H IUMANAS}

A ideia de aldeia global, o autor chamou de mito do encurtamento das distâncias, como se o mundo estivesse ao alcance de todos. Para ele, é uma falácia advogar a idéia de que todos são cidadãos do mundo, capazes de conhecer diferentes países e regiões, relacionarem-se com pessoas de todo o planeta, por meio de ferramentas tecnológicas, como a internet. É preciso considerar as disparidades sociais e econômicas e perceber que, nessa aldeia global, muitos estão excluídos.

Outro ponto da globalização como "fábula", complementa Santos, seria a tentativa de se fazer crer que a difusão instantânea de notícias realmente informa. Há um bombardeio de informações para onde quer que se olhe. Algo que acontece no Oriente Médio, por exemplo, rapidamente chega às telas de todo o mundo, seja pelos aparelhos de televisão ou nos monitores de computadores. Para o autor, a ideia de que isso é informação é mais um mito da globalização, já que, na verdade, existem filtros nessa transmissão de notícias, seleções e enfoques que não permitem que, de fato, conheçase a real situação do que ocorre do outro lado da Terra. Todo discurso midiático tem suas mediações ideológicas, mas é passado como se fosse neutro, realmente informando.

O segundo tipo de globalização é a que Santos denomina de "perversa", considerada enquanto a real e vigente. Essa, longe da ficção elaborada pela linguagem da indústria cultural, desnuda-se na vida real em que se observa a pobreza, a miséria, a desigualdade social, muito distante dos benefícios da globalização que pretensamente atinge a todos. Para grandes grupos econômicos que instalam fábricas no mundo inteiro, a globalização é positiva. Já para os trabalhadores explorados por baixos salários e longas jornadas dentro do processo de mundialização das empresas, principalmente em países mais pobres a globalização mostraria uma de suas piores faces.

Entre as consequências dessa globalização "perversa" também estariam males espirituais e morais, que causam cinismos, egoísmos e corrupção. É o que chama de "evolução negativa da humanidade" com a "adesão desenfreada a comportamento competitivo". Tudo acaba por se tornar transitório e obsoleto, conforme as circunstâncias, em especial as econômicas, causando uma depreciação de valores humanos de amor e solidariedade. Segundo Santos, o que se prega é que o dito mundo globalizado "exige" competitividade. É a competitividade entre países versus a solidariedade entre os povos. Um exemplo é o discurso de que é preciso inovar para competir internacionalmente e, raramente, inovar para cooperar com outras nações. "O consumismo e competitividade levam ao emagrecimento moral e intelectual da pessoa, à redução da personalidade e da visão de mundo, convidando, também, a se esquecer da oposição fundamental entre a figura do consumidor e a figura do cidadão" (SANTOS, 2000; p. 49). 
O autor cita que o "extraordinário progresso das ciências e das técnicas" é uma das bases da globalização que ele refuta, principalmente, no que se refere à tecnologia voltada para informação e produção de imagens e do imaginário. Aqui ele inclui a mídia, a publicidade e a propaganda, como as analisadas por este estudo. Para o autor, seriam essas ferramentas as formas usadas para sustentar a "fábula" da globalização, ocultando seu lado perverso. Segundo Santos (2000), essas teriam caráter ideológico e estariam a serviço do império do dinheiro, gerando "uma economização da vida social e pessoal". O grande capital se apóia nas bases técnicas para construir a globalização "perversa", adverte. "Uma manipulação da opinião pela publicidade" (SANTOS, 2000; p. 48).

Do ponto de vista econômico, a globalização teria criado um mercado avassalador dito global, colocado como capaz de homogeneizar o planeta. Existiria uma busca pela uniformidade a serviço dos atores hegemônicos, quando, de acordo com o autor, as diferenças locais acabam na verdade sendo aprofundadas. Essa busca pela homogeneização teria reflexo na criação de marcas globais e disseminação de ideias postas como padrões de consumo. Padrões destacados como exigências com a ampla divulgação por meio de anúncios publicitários e pela indústria cultural, mencionados no início do artigo.

Outro ponto citado por Santos seria o culto ao consumo e a defesa da morte do Estado. Se o discurso refere-se ao enfraquecimento do poder público e o fortalecimento da esfera privada, na prática, "o que vemos é o fortalecimento do Estado para atender as necessidades do mercado, em detrimento dos cuidados com a população com vida mais difícil" (SANTOS, 2000; p. 19). O autor ainda cita outras consequiências da globalização, como o desemprego crescente, aumento da pobreza, da fome e do desabrigo, crescimento no número de doenças, perda de qualidade de vida pela classe média, salário médio menor e menos qualidade na educação. Preocupações deixadas de lado face ao furor pelo lucro e busca incessante por vantagens financeiras, mesmo que em detrimento de algumas populações e países.

Embora descreva esse cenário negativo da globalização, Santos adverte, no entanto, que as suas ideias não devem ser vistas como fruto de um pessimismo e sim como uma defesa de que as mesmas bases técnicas poderiam servir a outros objetivos, se estiverem a serviço de outros fundamentos sociais e políticos, ou seja, de outra globalização, que seria a terceira forma descrita pelo autor. O final do século 20, para o autor, apontava essa possibilidade. Haveria chance de uma globalização "mais humana", em que as pessoas, e não mais o dinheiro, seriam a base de um processo de solidariedade entre os povos e ações conjuntas entre os países.

Um dos fatores que indicariam para essa nova história seria a enorme mistura de povos, raças, culturas e gostos em todos os continentes. Essa "mistura de filosofias" estaria acontecendo, de acordo com ele, também, e principalmente, em meio a populações aglomeradas em áreas cada vez menores. 


\section{HUM ANAS}

Santos chama de "a verdadeira sociodiversidade", que daria vazão à emergência de uma cultura popular para se contrapor à cultura de massa. $\mathrm{O}$ autor acredita que a mudança poderia vir de um movimento "de baixo para cima", dos "deserdados", dos "não opulentos", que vivem em países subdesenvolvidos. Ele reforça que o homem, e não mais o dinheiro, seria a base de uma nova globalização. As populações envolvidas no processo de exclusão acabam por relacionar suas carências e vicissitudes ao conjunto de novidades que as atingem. Uma tomada de consciência torna-se possível ali mesmo onde o fenômeno de escassez é mais sensível (SANTOS, 2000; p. 118). Os despossuídos passariam a viver uma relação conflituosa e até mesmo guerreira com a escassez, o que levaria a uma reflexão que conduziria para as mudanças. No entanto, não especifica de que maneira essa organização dos sujeitos se daria. Sua tese ressalta apenas que ela seria facilitada pelo fato de as populações excluídas viverem cada vez mais aglomeradas em territórios de pequena extensão, com chances, assim, de mobilizações pró-mudanças.

\section{Representações da globalização nos anúncios publicitários}

O estudo, doravante, irá se ater à análise das campanhas publicitárias apontadas no início deste texto, focando nas representações da globalização nos anúncios. Com relação à terminologia usada durante a análise, optou-se por usar publicidade e propaganda, assim como anúncios e peças, como sinônimos, embora seja necessário destacar que algumas teorias informam haver diferenciações entre os termos. A escolha foi por não sistematizar esses termos de forma diferenciada visto que o foco não são os conceitos em si e sim a verificação das representações da globalização nos anúncios ${ }^{11}$.

Neste anúncio ${ }^{12}$, apesar da já existência da televisão, o rádio com sintonia fina "despontava" como uma nova alternativa para os brasileiros.

\footnotetext{
${ }^{11}$ Sant'anna (2002) conceitua publicidade como o "ato de tornar público um fato, uma ideia". Já a propaganda é definida como a propagação de princípios e teorias, ligadas, historicamente, a questões religiosas e políticas. Enquanto a publicidade divulga, a propaganda busca implantar uma ideia. Do ponto de vista comercial, diz o autor, o anúncio visa vender, para isso, implantando idéias positivas sobre o produto, marca e suas necessidades. Mas, pela origem eclesiástica da palavra propaganda, muitos preferem usar o termo publicidade (SANT'ANNA, 2002; p. 76). Já para Carvalho (2003), a propaganda estaria mais ligada à mensagem política, religiosa, institucional e a publicidade seria relativa apenas a mensagens comerciais (CARVALHO, 2003; p. 9). Para este estudo, entende-se que a diferenciação é improcedente visto que a publicidade de objetos, nas campanhas escolhidas, serviços e marcas não intenta só apresentar o objeto de modo técnico e neutro, mas sim "vender" um estilo de vida, uma visão de mundo, manipulando signos e símbolos no intuito de instituir no indivíduo e nos grupos um comportamento consumidor em vez de cidadão.

12 O anúncio: "O rádio companheiro tem sintonia fina" traz informações técnicas, apresentadas em fonte menor, do lado esquerdo: "Sintonia fina: em ondas curtas, sintonia perfeita, com nitidez de som. Portátil: leve. Antena telescópica para ondas curtas. Antena "Ferroceptor" para ondas médias. Desenho moderno: beleza em estilo novo. Botões de controle laterais: simplifica o manuseio. Goooolll do Brasil". Logo abaixo, a marca Philips em destaque. Ao lado, a imagem do aparelho, apoiado por uma bola de futebol em um gramado com a frase: "traga o México para casa".
} 
Campanhas publicitárias na revista Veja: construções da globalização A.L. de Oliveira, A.M.R. Fanini \& M. Souza

Nele é possível perceber, a partir da frase "traga o México para casa", a ideia da globalização como "fábula", que assegura o encurtamento das distâncias, pois por meio da tecnologia há a possibilidade de trazer outro espaço para dentro da casa. Entretanto, ocorre a privatização do espaço visto que ele é interiorizado. $\mathrm{O}$ artefato promete a inserção globalizada, sem, contudo, neutralizar o sujeito. O individualismo está assegurado.

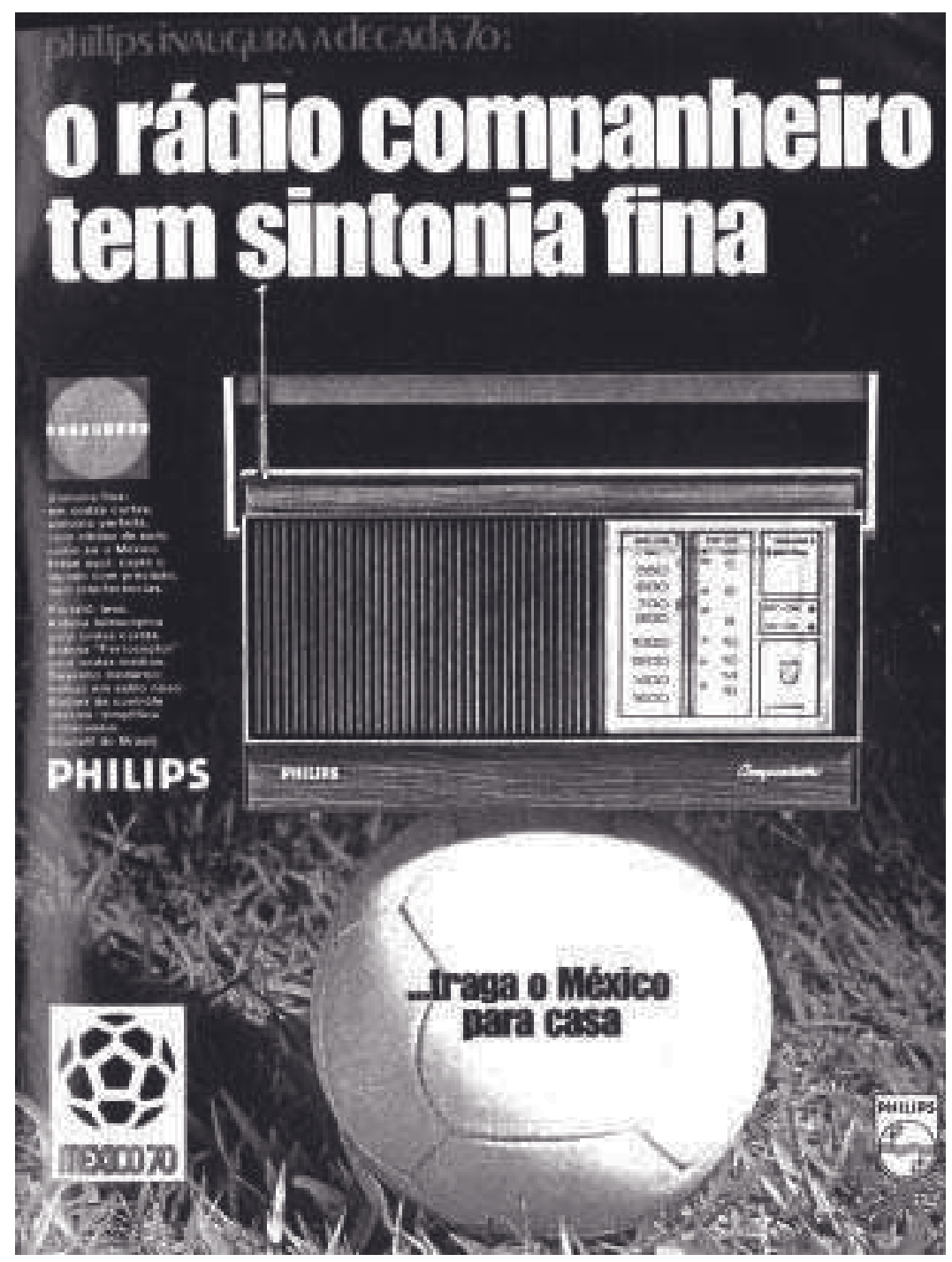

Figura 1

Anúncio do rádio Philips, publicado na revista Veja (5 de Maio de 1970). 
Essa representação da aldeia global também é reforçada por uma das frases que se observa ao lado da imagem do aparelho de som: "nitidez do som, como se o México estivesse aqui". Todavia, aqui, a noção de aldeia global aparece enfraquecida em relação à outra frase. A linguagem ora traz o México na sua totalidade, ora apenas uma suposta parte dele. O uso do vocábulo "como" revela a falácia da desterritorialização. Já a frase "capta o mundo com precisão, sem interferências", aponta novamente para a falácia do encurtamento de distâncias. Aqui, porém, vai mais longe, pois a tecnologia do rádio também se expande, prometendo alcançar o mundo. Esse é apresentado de modo imparcial e objetivo, dando ênfase a outro embuste, ou seja, o da objetividade técnica como se não houvesse mediações quando da transmissão, reforçando-se a globalização como farsa. Com relação à frase "o rádio companheiro", percebe-se uma linguagem que busca personificar o artefato tecnológico, podendo remeter-se ao que Santos (2000) chama de mazelas do ser humano. A tecnologia aqui apresentada é amigável. Seguindo a linha proposta por Santos, nesse caso, a publicidade institui a economização da vida pessoal e social, à medida que o rádio se transforma em companheiro.

\section{Obsolescência dos bens e culto à marca}

Dez anos depois da publicação do anúncio da Philips relacionado à Copa do Mundo, um anúncio de tênis chama a atenção. O calçado tem nome estrangeiro: TRX-Competition" ${ }^{13}$ (figura 2), com a promessa de "deixar para trás tudo o que você sabia sobre tênis de corrida!". Nota-se que o argumento principal para incitar a compra do produto é que ele recebeu "notável classificação 4 estrelas da revista Runner's World”, editada nos Estados Unidos.

\footnotetext{
${ }^{13} \mathrm{O}$ anúncio do tênis da marca Adidas tem como destaque o nome dado ao produto "TRX-Competition", com o slogan "Deixa para trás tudo o que você sabia sobre tênis de corrida!". Logo abaixo, mais informações: "Não é à toa que esse tênis (apenas 230g) mereceu notável classificação "4 estrelas" da revista Runner's World. Veja as vantagens insuperáveis que tornaram o TRX-Competition um Campeão Internacional de Corridas - o melhor, em sua classe, no Brasil". Do lado esquerdo, uma marca tipo selo com a imagem de quatro estrelas: "RW4-Star. Runner's World Magazine. Mark of Excellence". O destaque imagístico é para a foto do tênis com informações técnicas: "Cabedal de nylon com reforços em camurção. Rabicho alto e almofadado. Grande resistência na área do calcanhar com contraforte embutido. Proteção frontal. Baixa de formato especial garante liberdade para movimentação dos dedos. Entresola (SIC) e cunha em substância amortecedora e ultra-leve. Você nunca viu antes!". Na foto do solado, os itens: "Perfil de pinos de borracha próprio para aumentar a tração. Concentração dos pinos de acordo às áreas de maior ou menor exigência. Sola mais larga, maior área de estabilidade. Sola e palmilha embutida, de acordo com as mais recentes técnicas ortopédicas". Ao lado direito da foto do tênis, uma mulher, com blusa da Adidas, em uma corrida. No rodapé do anúncio, à esquerda: "Você ainda dispõe de três elegantes opções para vencer em seu TRX: branco com listas azuis e azuis com listas laranjas ou brancas" e, à direita, a logomarca da Adidas, com o slogan "a marca mundial das 3 listas". (Veja, Maio de 1980, p. 61).
} 


\section{TRX-Competition}

Deixa para trás tudo o que vocé sabia sobre tênis de corrida!

Nab e a toa que esae sents lapenus 230 of mereceu a notavel ciasaificaço " 4 estrelas"

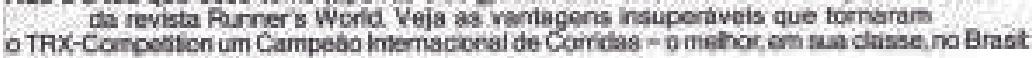

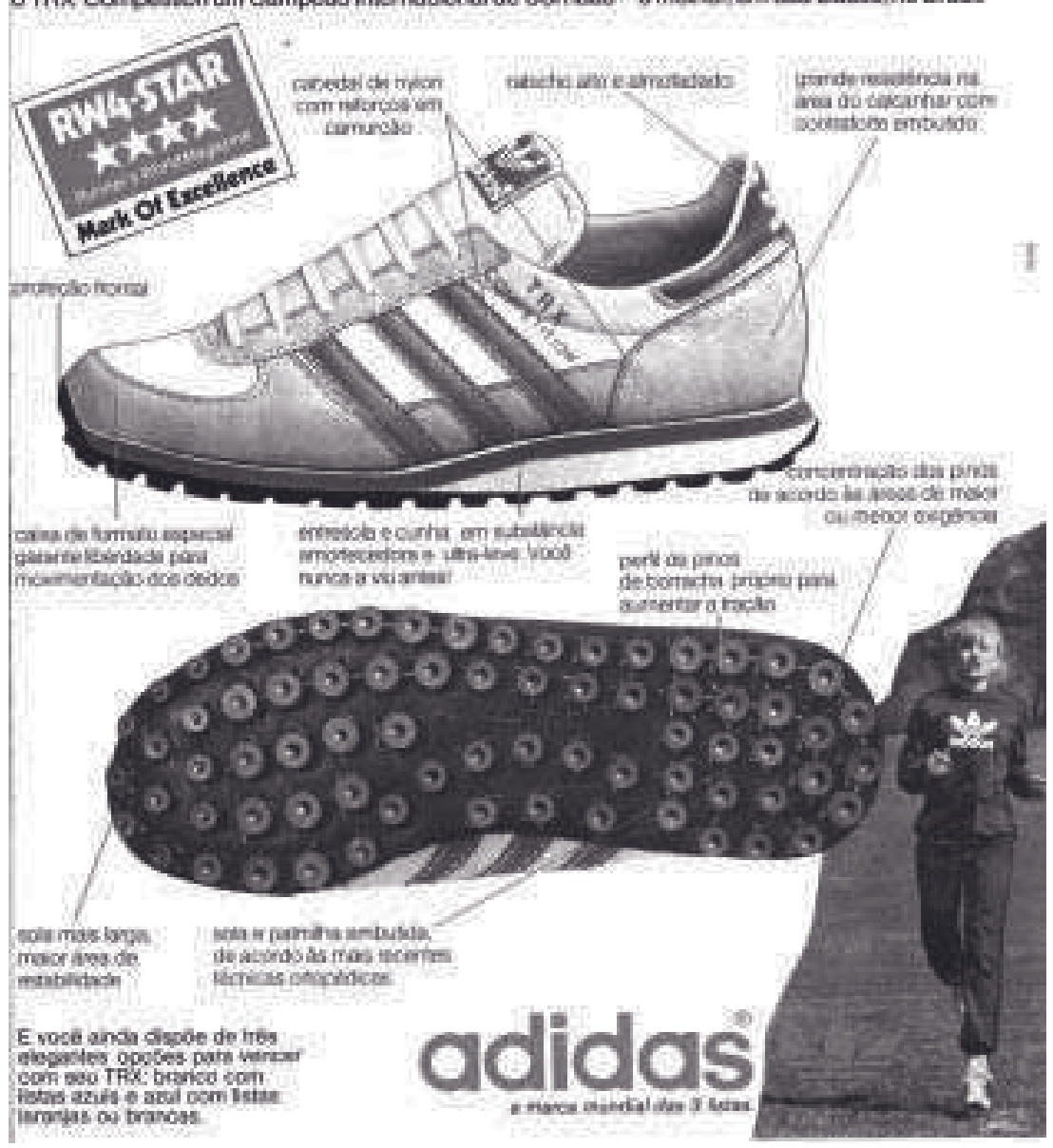

Figura 2

Anúncio tênis TRX-Competition publicado na revista Veja (7 de Maio de 1980).

Aqui, o discurso publicitário procura dar crédito a ele mesmo, pois cita uma revista como fonte de autoridade, o que parece conferir crédito à publicação. A peça apresenta um selo, com dizeres em inglês, informando que o tênis tem a marca da excelência: "Mark of excellence", valorizando o renome internacional. O uso desse idioma procura conferir prestígio ao discurso publicitário e o globaliza. 


\section{HUM AN AS}

Observa-se ainda que a linguagem publicitária "traduz" a linguagem técnica sobre o tênis em nove micro-textos, com especificações sobre cada item do produto anunciado. O registro linguístico está entre o formal e o informal, buscando transmitir os benefícios dessa nova tecnologia que se encontra "no topo", deixando os outros tênis já existentes obsoletos. Em um mundo competitivo e com prioridade absoluta para o que traz vantagens econômicas, tudo se torna transitório e obsoleto. O capitalismo vive da obsolescência programada e imediata e a publicidade reforça esse norte. É necessário sempre consumir o novo. O "velho" é descartado, como propõe o anúncio. Verifica-se o incentivo constante ao consumo, razão da existência do Capitalismo.

Embora a ênfase recaia no produto, há uma exaltação da marca. Nesse caso, a multinacional Adidas, "a marca mundial das 3 listas", como lembra o anúncio. Relembrando ainda Santos (2000), a globalização perversa tem como objetivo econômico criar um padrão de consumo homogêneo, alavancando assim um grande mercado mundial, desconsiderando as culturas e demandas locais.

Klein (2003) também trata da questão das marcas globais, como neste caso, a Adidas, e sua relação com o processo de globalização. De acordo com a autora, as marcas corporativas reforçam o processo de que a publicidade vende ideias em vez de produtos, acabando por transformar "nossa cultura e nossas vidas". Isso porque, segundo ela, "a marca exige a absorção constante de tudo o que tem significado e é novo em nossa cultura" (KLEIN, 2003; p. 176). Tanto essa autora quanto Santos estudam os impactos da globalização no mundo do trabalho, pois sabe-se que o capital é móvel, mas nem todos os trabalhadores o são. A ênfase na marca e no produto oblitera totalmente o processo de produção que não raras vezes se dá por intermédio de exploração e desterritorização do mundo do trabalho visto que grandes companhias tem migrado para países pobres onde podem obter mais lucro devido à mão-de-obra desprotegida pelos Sindicatos e pacificada pelo Estado a serviço do grande capital. Klein (2003) estuda as consequências do fenômeno das marcas globais e o processo de terceirização da produção. A globalização presente no anúncio é também perversa uma vez que não focaliza a produção e sim a circulação de bens.

A marca é importante porque muda nossa cultura, alimenta-se de nossas ideias e de nossos espaços públicos, mas também é importante porque muda a maneira como trabalhamos. Eu disse que a marca transcende o mundo dos produtos. Quando as empresas decidem internamente que vão entrar no negócio das ideias e sair do negócio dos produtos, isso significa que o ato de produção e as pessoas que fabricam os produtos recebem um rebaixamento significativo na hierarquia econômica[... ] 


\section{Campanhas publicitárias na revista Veja: construções da globalização A.L. de Oliveira, A.M.R. Fanini \& M. Souza}

A melhor maneira de conseguir esse tipo de ganho é fazer com que outros fabriquem seus produtos. Começar a terceirizar o próprio produto (KLEIN, 2003; p. 181).

A ênfase na mundialização também é assegurada por meio de expressões como "campeão internacional" e o selo de qualidade recebido transcrito em inglês, sem deixar de citar o slogan da Adidas, que se apresenta como sendo "a marca mundial das 3 listas".

Sobre a oferta do tênis com tecnologia estrangeira, lembra-se aqui o que diz Barber (2003) a respeito do que ele chama de "cultura McWorld"14. Segundo ele, há uma tentativa de diminuir os padrões locais, buscando universalizar hábitos, principalmente oriundos da cultura dos Estados Unidos. Vislumbrase "um futuro reunindo todos os países em um vasto parque de temática mundial", que estariam "em rede pelas tecnologias da informação, pelas trocas comerciais e pela indústria do espetáculo” (BARBER, 2003; p. 42).

\section{Qualidade de vida e consumo}

Outros conceitos de globalização foram verificados na propaganda do equipamento de som $C C E^{15}$. O anúncio inicia com a frase "Esse mundo é seu".

\footnotetext{
${ }^{14}$ Para esse autor, como também para Jameson, já citado, a globalização econômica e cultural, apesar de se vincular a uma cultura empresarial transnacional, do capital financeiro, não deixa ainda de se atrelar fortemente à cultura dos Estados Unidos. O neoliberalismo americano se espraia pelos outros países, sendo um forte centro de influência cultural, política e impulsionando a economia em moldes capitalistas. A cultura McWorld aponta para essa diretriz de globalização cultural exportada pelas grandes corporações americanas, gerando padrões de consumo que se desejam totalizantes. $\mathrm{Na}$ visão de Milton Santos, aqui referenciado, essa cultura é muito poderosa, mas poderá ser obstaculizada à medida que os países da periferia do capitalismo, em especial, resistam a ela a partir de suas especificidades econômicas e culturais. Outra globalização é possível, pautada em valores humanos e não essencialmente de mercado.

${ }^{15}$ Transcrevendo o anúncio, no topo superior, a frase (negrito, fonte maior que as demais); "Esse mundo é seu". A imagem é de uma mulher calçando o sapato (à esquerda), um homem (à direita). Ambos aparecem da cintura para baixo. O som da $C C E$ aparece ao fundo. Abaixo da foto: "A gente vive para conquistar. Lógico que esta não é a maior preocupação. Mas, o interessante, é que sempre alguma coisa boa acontece quando o som está por perto. Coincidência? Não sei. O que eu sei é que o som faz um mundo mais meu, mais descontraído. Talvez por isso as coisas boas me acontecem...". Abaixo, uma foto do som com informações técnicas: "Módulo rack SSK-3070. C-126 - Tocadiscos automático e manual. Compensador de força centrífuga; Lift; braço tubular balanceado; motor síncrono de 4 pólos. SR-3070 - Receiver AM, FM/Stereo. Potência de 120 watts IHF; Distorção harmônica total inferior a 0,1\%. CD-6060 - Stereo Cassette. Carregamento frontal, seleção de fitas (polarização equalização) $\mathrm{CrO} 2, \mathrm{FeCr}$ e normal; Dolby NR, filtro MPX, porta cassette com sistema hidráulico. CL-770 - Caixas acústicas; sistema radiador passivo de 3 canais; impedância de 8 ohms; potência máxima admissível 35 W RMS; pico de $70 \mathrm{~W}$; resposta de frequiência $35 \mathrm{~Hz}-20 \mathrm{KHz}$; controles agudos e médios". Ao lado esquerdo, a marca "CCE equipamentos de som" (Veja, Maio de 1980; p. 2).
} 


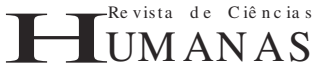

\section{Esse mundo é seu.}

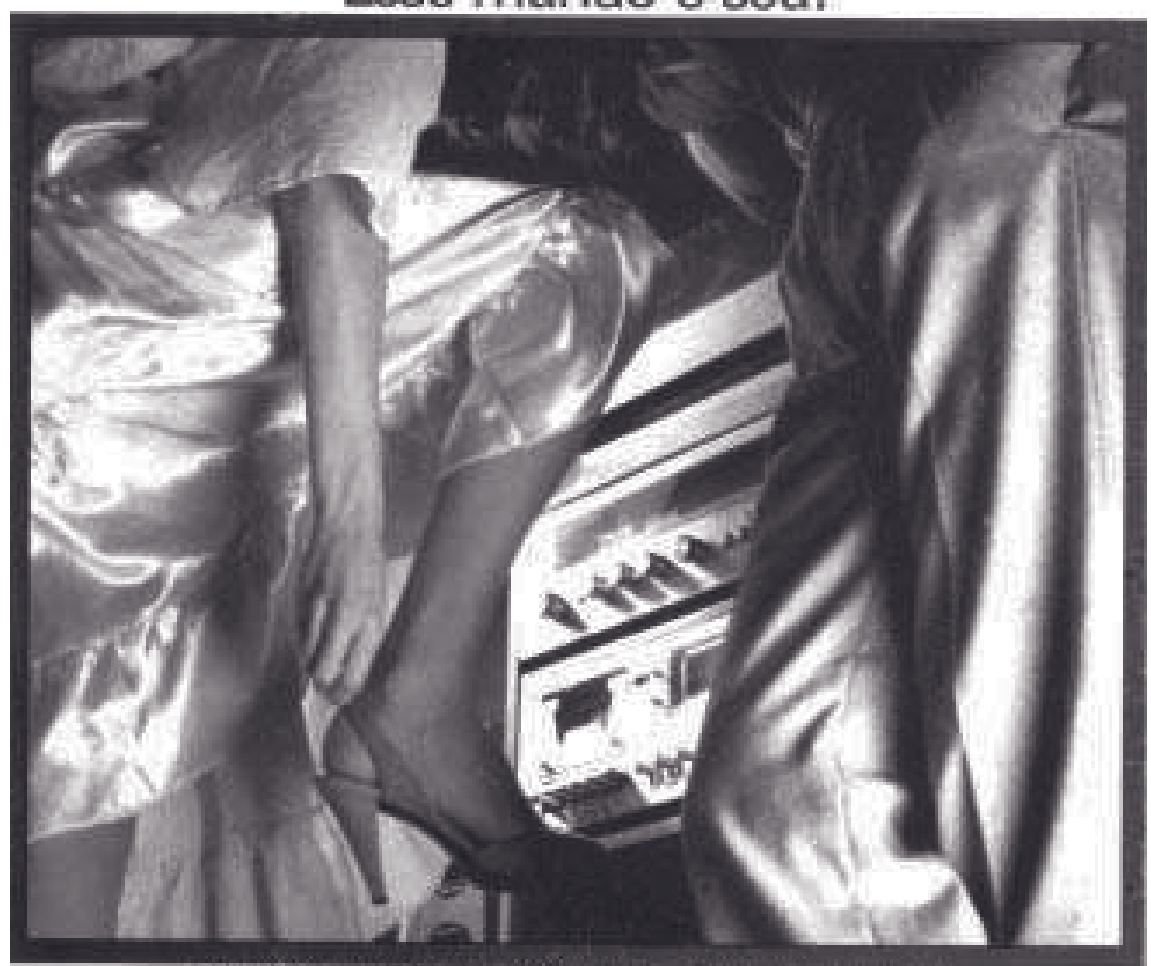

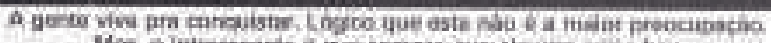

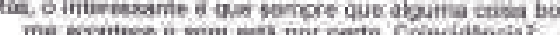

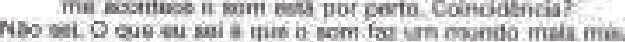

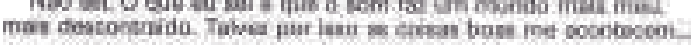

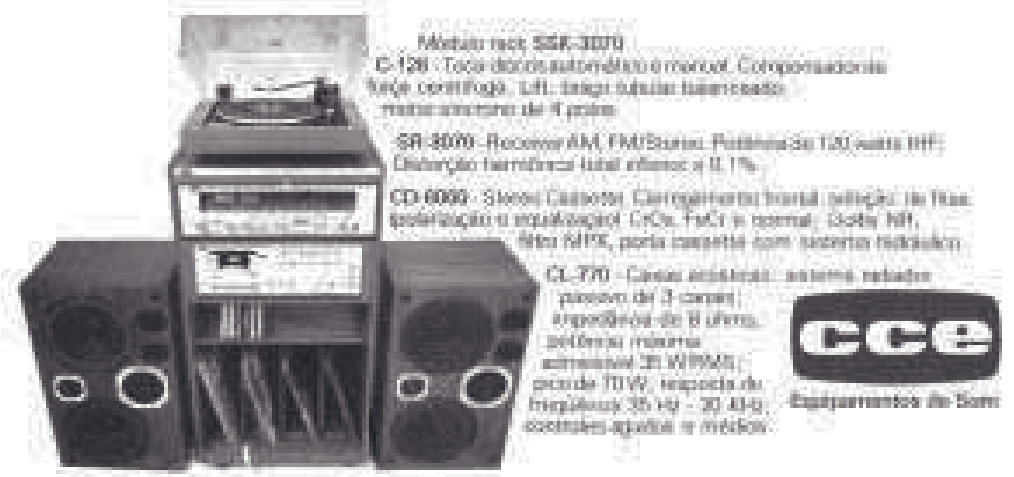

Figura 3

Anúncio aparelho de som CCE publicado na revista Veja (7 de Maio de 1980). 
Aqui também a noção de aldeia global é privatizada, distanciando o cidadão do consumidor. Nessa peça, opta-se pela ideia de qualidade de vida quando da aquisição de certa tecnologia, valorizando o ato de consumir, como afirma Santos, buscando resumir o valor da vida aos bens materiais que se adquirem, mercantilizando-se valores morais e éticos.

Verifica-se que, nesta peça publicitária, o texto verbal é constituído de duas partes distintas. Uma em que as informações técnicas são passadas com descrição sumária do artefato e de seus componentes tecnológicos, postadas ao lado do produto figuratizado. Já no outro texto, que recebe destaque, a linguagem se formaliza por estratégias de sedução, generalização, intimismo. Nesse discurso, há primeiramente uma tentativa de englobar a "todos" que vêem a campanha por meio da frase "a gente vive para conquistar". Essa inserção geral, ou seja, a sua globalização objetiva seduzir o comprador, colocando-o em um grupo de privilegiados visto que esses são conquistadores, ou seja, são vencedores. Na frase seguinte, "lógico que esta não é a maior preocupação", a idéia de conquista incessante é parcialmente neutralizada visto que o consumidor deve voltar para o foco, ou seja, o produto. Entretanto, aí, já houve uma redefinição do consumidor à medida que o insere em um grupo privilegiado. A partir desse ponto, pode-se retornar para o receptor e o que era global (todos) se torna "meu". O discurso agora parte para o intimismo do "eu", introduzindo o objeto da publicidade, nesse caso, o som, que acompanha o sujeito consumidor em tudo que "lhe ocorre de bom". Portanto, primeiro houve uma ênfase no coletivo, redefinindo-o em outro status social. Depois, na privatização do eu em relação ao social. A globalização, a partir da tecnologia do artefato aparelho de som, comungaria a todos, mas também preserva o individualismo. Nota-se ainda uma presença mais forte, do que nos anúncios analisados anteriormente, de um processo de venda de ideias maior que a do produto em si. Divulga-se o conceito globalizante de que o "mundo é seu", de que a tecnologia do som faz com que "coisas boas aconteçam", sem ser incisivo ou usar a linguagem autoritária do "compre já". Os modelos feminino e masculino tem ênfase nos corpos, evitando-se a imagem dos rostos, indicando intimismo, privacidade e sexualidade. O que conta não é mais tanto o aparelho, mas o bem-estar que ele pode proporcionar ao consumidor. A qualidade de vida está em destaque.

\section{Consumidor calado diante dos apelos publicitários}

No ano 2000, outros anúncios demonstram a representação de alguns conceitos da globalização na revista Veja. Fora do contexto deste estudo ou desvinculado do conjunto da revista, um leitor desavisado poderia achar que o 


\section{H UM ANAS}

anúncio do relógio vendido pela H.Stern (Figura 4) fora tirado de alguma publicação estrangeira ${ }^{16}$. O texto é veiculado no idioma inglês. Sem a intenção de tecer uma análise conservadora sobre o uso da língua, o que se observa aqui é outro ponto da ideia de mundo globalizado: a "exigência" de se saber novos idiomas. Afinal, a "fábula" da globalização prega que somos cidadãos do mundo e é preciso dialogar por meio de uma língua "universal", sendo o inglês aqui proposto como tal. Além disso, a apresentação em língua estrangeira mostra um anúncio com característica clara de segmentação visto que os produtos H.Stern, marca de venda de jóias, são adquiridos pelas classes abastadas que desejam diferenciação.

Pela imagem, pode-se perceber, mesmo que sem o conhecimento da língua, que se trata do anúncio de um relógio. Ao fazer a tradução, o texto diz "força nem sempre é um grito" e, em destaque sobre o relógio, complementa com a seguinte mensagem: "força secreta" ou "força interior". Essa mensagem é reforçada pelo destaque imagístico, em que aparecem duas fotos da mesma mulher: primeiro gritando e, à direita do leitor, com a mão indicando "silêncio". Aqui, o ato de consumir é extremamente valorizado, pois constitui outra realidade psíquica ("new alterego") à medida que confere poder interior ao consumidor, revelando-se aí a globalização perversa à medida que o ato de comprar redefine moralmente o comprador. Apela-se também para a questão de gênero, uma vez que o público alvo é o feminino e este se destaca não pela força física, própria dos homens, mas pela força interior adquirida por um processo de mercantilização do eu. A emancipação feminina advém do consumo de bens materiais de prestígio. Ainda que o receptor desconheça a tradução do texto, a análise da imagem lembra a necessidade de se calar diante do apelo e força do consumo. Na imagem à esquerda em que o relógio ainda não foi adquirido (note-se que o espaço ocupado pelo relógio é aí menor, indicando a sua não aquisição), a figura feminina se apresenta com sinais de desequilíbrio e irracionalidade, beirando ao primitivo. Essa imagem negativa é reafirmada pela frase "a força nem sempre é um grito". Já na imagem à direita, apresenta-se calma, equilibrada, racional visto que detém força interior, ou seja, é civilizada. Assim, a aquisição civiliza, mas não pacifica, pois oferece algo de maior prestígio, ou seja, força moral. Entretanto, subliminarmente ocorre certa imagem de passividade, pois o silêncio é esperado frente ao consumo. Antes do consumo,

\footnotetext{
${ }^{16}$ No canto extremo direito do anúncio, a marca "TAG Heuer. The original sports watch. Since 1860. Swiss Mode", que apresenta o relógio suíço vendido pela H.Stern. O destaque é para duas fotos, da mesma mulher: a primeira, com o rosto franzido e expressão de grito. E, ao lado, a mesma personagem com rosto sereno e dedo indicador sobre os lábios, indicando silêncio. Abaixo: Strength isn't always a shout. Inner Strength.”, cuja tradução literal é: “A força não é sempre um grito. Força interior." Em seguida, Kristin Scott Thomas, nome da atriz britânica, modelo da campanha. Por fim, a foto do produto e a frase "New Alter Ego" ou "Novo alterego". No canto extremo abaixo à esquerda, a marca H.Stern e a única frase em português do anúncio: "Representante oficial no Brasil (0800-22-7442) VE 0186. E-mail: tmk@hstern.com.br.
} 
o grito, a revolta, os comportamentos desordenados; após, a temperança e a civilidade. Esse discurso publicitário acerca da tecnologia vincula o item diretamente ao comportamento, influenciando e constituindo realidades psíquicas. $\mathrm{O}$ uso de certa tecnologia e artefato tem o "poder" de mudar a psique humana, contribuir para a emancipação feminina e civilizar. Outro ponto relacionado ao processo de globalização vincula-se à origem do artefato, pois se trata de um relógio suíço, fabricado fora do Brasil e importado pelo seu representante oficial. Santos (2000) aborda que um dos principais objetivos da globalização é ampliar o mercado consumidor de produtos fabricados pelos países ditos desenvolvidos. Neste caso, um relógio com o prestígio e a tradição de ter sido feito da Suíça (segundo o anúncio, desde 1860).

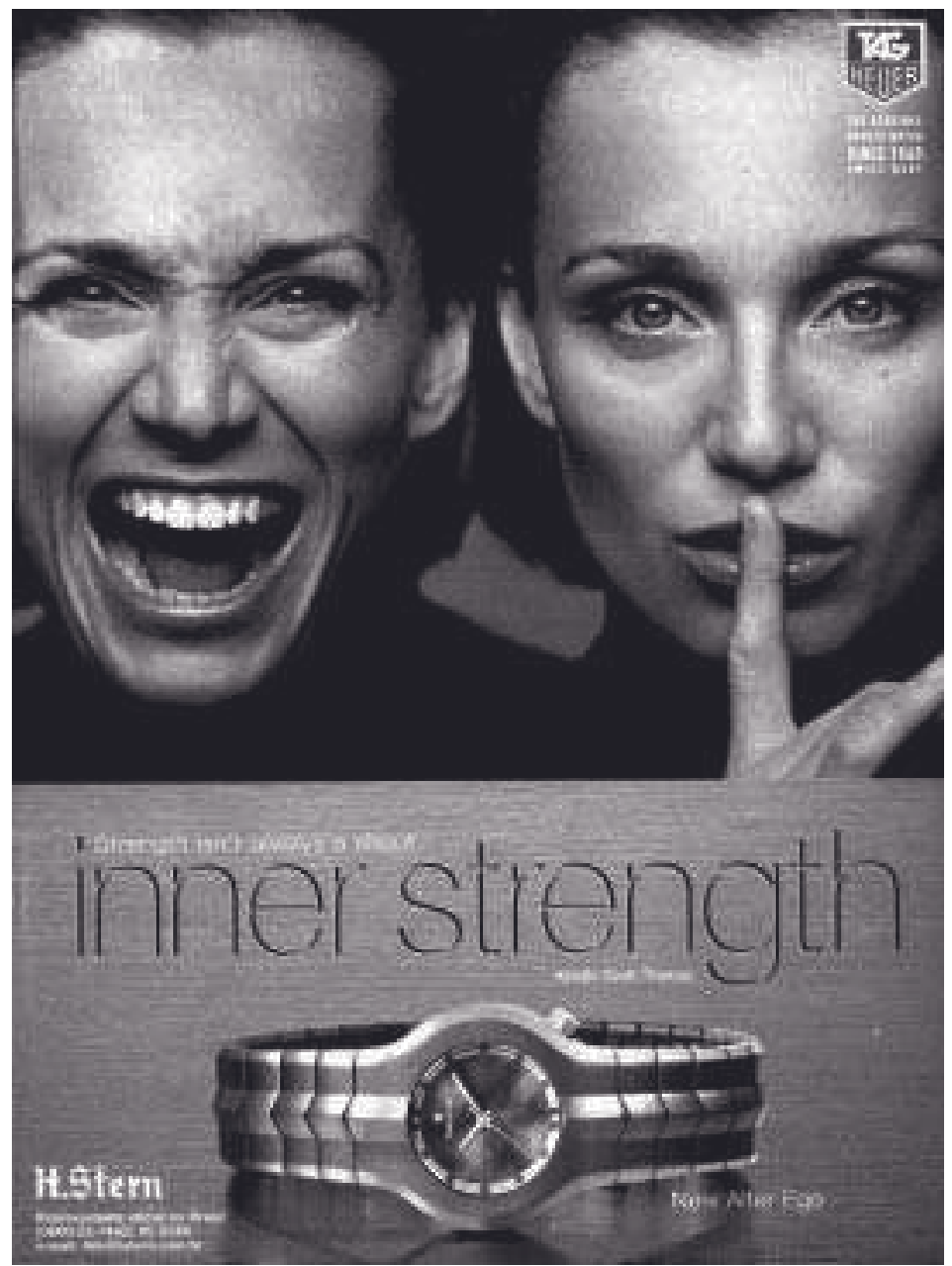

Figura 4

Anúncio de relógio da H.Stern publicado na revista Veja (3 de Maio de 2000). 


\section{HUMANAS}

\section{Considerações finais}

A análise das quatro peças publicitárias publicadas pela revista Veja e selecionadas para a presente pesquisa corrobora a pressuposição de que a linguagem da publicidade colabora com o reforço de ideias positivas referentes à globalização. Não se trata de um discurso totalitário para convencer as pessoas sobre os supostos benefícios do processo de mundialização nas mais diferentes áreas, mas um discurso comercial, sedutor e aliciante.

A linguagem publicitária, embora venda produtos e serviços, também tenta incutir um estilo de vida, uma visão de mundo, consolidando a ideologia da sociedade que a mantém. Oferece o mundo, o encurtamento de distâncias, informações instantâneas, benefícios morais e materiais, internacionalização de consumo; pertencimento a grupos seletos, à comunidade internacional de prestígio e o aumento da qualidade de vida. Entretanto, esses benefícios sempre preservam o espaço e a vida privada, assegurando o individualismo, enfatizando-se muito mais o consumidor em detrimento do cidadão. A publicidade se institui como ferramenta de consumo de produtos, bens e serviços e para alcançar êxito, foca-se em benefícios imateriais que supostamente advirão do consumo. A informação referente aos bens é minimizada e enfatizam-se valores simbólicos vinculados à afeição, intimismo, amizade, coletivismo.

Não estão em questão os benefícios reais de determinadas inovações tecnológicas, como um aparelho de som, um par de tênis, um relógio, uma tecnologia da informação. O que autores, como Santos (2000), questionam é o uso da publicidade e da tecnologia como sustentáculo da globalização como "fábula" e "perversa". Um possível estrangulamento das culturas locais e a homogeneização da língua e de padrões de vida e consumo são colocados como favoráveis para todo o planeta. Não é considerado seu lado negativo, como a exploração da mão-de-obra em países subdesenvolvidos, a redução do papel do Estado para atender as mazelas da população, o culto ao consumo desenfreado, a ascensão do consumidor e a queda do cidadão. A degradação da moral também é enfatizada pelo autor uma vez que a globalização, sendo a expansão do modo de produção capitalista, tende a mercantilizar todos os valores existenciais, destacando a felicidade a partir de bens materiais já programados para a sua obsolescência, razão de fortalecimento do capital.

O que Santos defende é o uso dessas mesmas bases técnicas, o que inclui a publicidade, com uma motivação "mais humana", em que o sistema financeiro não seria o comandante desse processo e sim interesses mais fraternos e solidários da sociedade. Por hora, conclui-se que a linguagem publicitária das campanhas analisadas na revista Veja por este artigo vai totalmente ao encontro do estudo de Santos sobre a globalização como "fábula e perversa", 
enfatizando-as, e de encontro ao ideário advogado pelo autor sobre uma outra globalização mais humana, mais fraterna e que considere as especificidades culturais e a grande massa de excluídos e deserdados do sistema.

\section{Referências bibliográficas}

BARBER, B.R. Cultura McWorld. In: D. DE MORAES (Org.). Por uma outra comunicação: mídia, mundialização cultural e poder. p. 38-54. São Paulo: Record, 2003.

BAUDRILlHARD, J. A sociedade de Consumo. São Paulo: Martins Fontes, 1996.

BAUMAN, Z. Sociedade individualizada: vidas contadas e histórias vividas. Trad. de José Gradel. Rio de Janeiro: Zahar, 2008.

HOBSBAWN, E. A era dos extremos: o breve século XX (1914-1991). São Paulo: Companhia das Letras, 1995.

CARVALHO, N. Publicidade: a linguagem da sedução. São Paulo: Ática, 2003.

FOUCAULT, M. A ordem do discurso. São Paulo: Loyola, 2003.

JAMESON, F. Pós-Modernismo - a lógica cultural do capitalismo tardio. São Paulo: Ática, 1997.

KLEIN, N. Marcas globais e poder corporativo. In: D. DE MORAES (Org.). Por uma outra comunicação: mídia, mundialização cultural e poder. São Paulo: Record, 2003.

ORLANDI, E. Análise de discurso: princípios e procedimentos. Campinas: Pontes, 1999.

MCLUHAN, M. Os meios de comunicação como extensão do homem. 1964 (http://www.4shared.com/get/ok1zud4z/mcluhan_Marshall_-_Os_Meios_de.html, acesso em 22 de Fevereiro de 2011).

MORAIS, F. Chatô: o rei do Brasil. São Paulo: Companhia das Letras, 1994.

NASCIMENTO, P. Jornalismo em revistas no Brasil: um estudo das construções discursivas em Veja e Manchete. São Paulo: Annablume, 2002.

RAMONET, I. O poder midiático. In: D. DE MORAES (Org.). Por uma outra comunicação: mídia, mundialização cultural e poder. São Paulo: Record, 2003. 
SANT'ANNA, A. Propaganda: teoria, técnica e prática. São Paulo: Pioneira Thomson Learning, 2002.

SANTOS, M. Por uma outra globalização: do pensamento único à consciência universal. São Paulo: Record, 2000.

SOUZA, M. As marcas escritas que orientam a prosódia no texto publicitário. Ditoefeito Revista de Comunicação da UTFPR, 2(1): 15-18, 2009.

VILLALTA, D. C. Artesanato industrial na produção jornalística de 1968. O surgimento da revista Veja no contexto da modernização brasileira. Dissertação de Mestrado. Pós-Graduação em Comunicação Social, Universidade Metodista de São Paulo, 1999. 